\title{
A Study on Performance of Lycopersicon esculentum under Poplar Based Agroforestry System in Subtropics of Jammu (J\&K)
}

\author{
Lalit Upadhyay $^{1}$, S. K. Gupta ${ }^{1}$, Sandeep Sehgal ${ }^{1}$ and Arvinder Kumar ${ }^{2 *}$ \\ ${ }^{1}$ Division of Agroforestry, SKUAST Jammu, India \\ ${ }^{2}$ K.V.K. Reasi, SKUAST Jammu, India \\ *Corresponding author
}

\section{A B S T R A C T}

K e y w o r d s
$\begin{aligned} & \text { Agroforestry, } \\ & \text { Poplar, Tomato, } \\ & \text { Vegetables }\end{aligned}$
Article Info
$\begin{aligned} & \text { Accepted: } \\ & 20 \text { August } 2020 \\ & \text { Available Online: } \\ & \text { 10 September } 2020\end{aligned}$

\section{Introduction}

Agroforestry plays a key role in the Indian economy by way of tangible and intangible benefits. Agroforestry can simultaneously satisfy three important objectives viz., protecting the ecosystems; producing a highlevel output of economic goods; and increasing income and basic needs of rural population besides maintaining the resource base. In general, it helps in increasing overall productivity in the rainfed areas and in the arid and semi-arid regions in particular. Changing priorities in avenues like optimization of farm productivity, carbon sequestration, green energy and employment generation are now being focused through agroforestry. Among indigenous species, only Populus ciliata is grown to a noticeable extent in plantation programmes in the Himalayan region of North India by State Forest Departments (SFD) near villages in mixture with other hardwood species and plantation around orchards. Poplars are valuable for nontimber uses such as ornamental plantings, windbreaks, visual screens, and soil stabilizers. Many cereals viz. wheat, pulses, medicinal plants and vegetables crops have been tried as intercrops under poplar all over the world, but the literature on growing of vegetables as intercrop with poplar is not available for subtropics of Jammu and 
Kashmir. Tomato (Lycopersicon esculentum L.) is a well known and very popular vegetable grown successfully throughout the India. This vegetable contains $1.98 \mathrm{~g}$ protein, $320 \mathrm{IU}$ vitamin-A, $1.8 \mathrm{mg}$ iron and $31 \mathrm{mg}$ vitamin-C in $100 \mathrm{~g}$ edible tomato (Bose and Som, 1986) and is popular for its nutritional value and diversified use like salad, juice, sauce etc.

Present study was attempted to explore the possibilities of growing vegetable crops viz. Tomato, Brinjal, Okra, Potato, Cabbage and Spinach as intercrop under poplar plantation with the following objectives to study the effect of light intensity and integrated nutrient application on growth, physiology and yield of intercrop.

\section{Materials and Methods}

The present study was carried out at experimental farm Chatha, Division of Agroforestry, Sher-e-Kashmir University of
Agricultural Sciences \& Technology (SKUAST) Jammu. It is located at an altitude of $325 \mathrm{~m}$ above mean sea level, between $32^{0} 73^{\prime} \mathrm{N}$ latitude and $74^{0} 87^{\prime} \mathrm{E}$ longitude. The average rainfall of the experimental location was about 1000-1200 mm, of which 75-80 per cent is received during July to September and rest 20- 25 per cent during winter months in December to February. The maximum temperature remained upto $45^{\circ} \mathrm{C}$ during May to June and minimum falls to $1^{\circ} \mathrm{C}$ during December- January. The study consisted of two structural components viz. Poplar (Populus deltoides) tree as woody perennial and tomato crop as intercrops in two seasons. In addition, effect of NPK, Farmyard Manure (FYM) and Vermi-compost (VC) was studied with and without Poplar trees. Two experiments with same treatments were laid out separately (i) in open and (ii) under poplar plantation in 2017 and 2018. The trial was laid in Factorial Randomized Block Design (FRBD) design with following treatments:

\begin{tabular}{|l|c|}
\hline Recommended dose of NPK/ control & $\mathbf{T}_{1}$ \\
\hline $\mathbf{5 0 \%}$ N+ 50\% N through FYM + (Recommended P and K) & $\mathrm{T}_{2}$ \\
\hline $100 \%$ N through FYM+ (Recommended P and K) & $\mathrm{T}_{3}$ \\
\hline $\mathbf{5 0 \%}$ N+ 50\% N through VC+ (Recommended P and K) & $\mathrm{T}_{4}$ \\
\hline $100 \%$ N through VC+ (Recommended P and K) & $\mathrm{T}_{5}$ \\
\hline
\end{tabular}

Plant height of intercrops were recorded from base to tip of the main leading shoot using meter scale and reported as mean in centimeters. Total numbers of fruits per plant were counted and the mean number of the fruits was reported. Total numbers of fruits per plant were counted and the mean number of the fruits was reported. Average fruits weight in gram per plant was taken by weighing all the fruits on a plant, dividing that by the total number of fruits per plant. Total crop yield per hectare was calculated by multiplying the average yield of single plants with total number of plants in one hectare area. The yield was expressed in quintals per hectare. Bio economics of the system was estimated by calculating the cost of cultivation, gross and net returns per hectare. All these parameters were calculated on the basis of prevailing market price of inputs and output (produce) at the time of termination of the experiment.

\section{Results and Discussion}

Intercropping and integrated nutrient application showed significant variation in plant height, number of fruits per plant, average fruit weight and yield per hectare due to different doses of inorganic and fertilizer. 
Effect of intercropping and integrated nutrient application on growth and yield parameters is described below:

\section{Plant height (cm)}

The plant height of intercrop was governed by different treatments compared. Data presented in table 1 indicated that the plant height of tomato was significantly differed in all the five treatments in both the years under sole crop. Amongst the nutrient combinations, $\mathrm{T}_{1}$ showed the maximum plant height $(63.02 \mathrm{~cm})$ followed by $\mathrm{T}_{2}(61.90 \mathrm{~cm})$ and $\mathrm{T}_{4}(61.62 \mathrm{~cm})$ in kharif 2017. Whereas in 2018 again $T_{1}$ $(65.14 \mathrm{~cm})$ recorded the maximum plant height, followed by $\mathrm{T}_{2}(64.02 \mathrm{~cm})$ and $\mathrm{T}_{4}$ $(63.74 \mathrm{~cm})$.

The lowest plant height was recorded in $\mathrm{T}_{5}$ $(58.63 \mathrm{~cm}$ and $60.74 \mathrm{~cm})$ for 2017 and 2018 respectively. However, under the tree canopy the plant height varied significantly and maximum plant height was attained in $T_{1}$ $(61.30 \mathrm{~cm})$ followed by $\mathrm{T}_{2}(60.66 \mathrm{~cm})$ and $\mathrm{T}_{4}$ $(60.41 \mathrm{~cm})$ in 2017 . In year 2018, in treatment combination $\mathrm{T}_{1}(63.23 \mathrm{~cm})$ recorded maximum plant height followed by $\mathrm{T}_{2}$ (62.59 $\mathrm{cm})$ and $\mathrm{T}_{4}(62.34 \mathrm{~cm}) . \mathrm{T}_{5}$ observed the minimum height of $59.72 \mathrm{~cm}$ and $59.77 \mathrm{~cm}$ in 2017 and 2018 respectively.

The values were significantly reduced when tomato was grown in the shade of poplar trees. Significant difference was recorded in interaction effect of intercrop and fertilizer application in year $2017 \& 2018$.

The result shows the importance of nitrogen for the proper growth of the plant, which is in agreement with the publication of Tisdale et al., (2003). The finding in the experiment is also corroborated with the results of Makinde et al., (2016) which obtained that application of RDF of NPK attains the maximum height in growth. This kind of reduction in height in agricultural crops was already recorded under Simarouba glauca by Mohanraj (2004) and in sorghum under Ailanthus excelsa based agro forestry system by Divya et al., (2005).

\section{Number of fruits per plant}

Table 2, revealed that the number of fruits per plant of tomato differed significantly due to fertilizer treatments in both the years under sole crop. Control was significantly superior over all the treatments. Amongst the nutrient combinations, $\mathrm{T}_{1}$ showed the maximum number of fruits (9.53) followed by $\mathrm{T}_{2}$ (8.60) and $\mathrm{T}_{4}(8.54)$ in 2017. Also in 2018 again $\mathrm{T}_{1}$ (9.73) recorded the maximum number of fruits, followed by $\mathrm{T}_{2}$ (8.78) and $\mathrm{T}_{4}(8.63)$.

The lowest number of fruits were recorded in $\mathrm{T}_{5}$ (6.69 and 6.83) for the year 2017 and 2018 respectively. Under the tree canopy the number of fruits varied significantly and maximum number of fruits were attained in $\mathrm{T}_{1}$ (5.73) followed by $\mathrm{T}_{2}$ (5.18) and $\mathrm{T}_{4}(5.11)$ in 2017.

In year 2018, maximum number of fruits were also recorded in treatment combination $\mathrm{T}_{1}$ (5.85) followed by $\mathrm{T}_{2}$ (5.39) and $\mathrm{T}_{4}(5.33)$. $\mathrm{T}_{5}$ showed the minimum number of fruits of 4.76 and 4.97 in 2017 and 2018 respectively. Shade significantly affected the number of fruits in tomato.

Intercrop and fertilizer application made significant affect on number of fruits per plant in $2017 \& 2018$. The lower number of fruits per plant under shaded condition was probably due to poor photosynthetic capacity of plants.

Treatments affected the fruit set in plants, as nitrogen promotes the fruit set. Similar results of NPK dose was reported by Nnabude et al., (2015) also. 
Table.1 Effect of intercropping and integrated nutrient application on plant height $(\mathrm{cm})$ of tomato

\begin{tabular}{|c|c|c|c|c|c|c|}
\hline \multirow[b]{2}{*}{ Treatments } & \multicolumn{3}{|c|}{2017} & \multicolumn{3}{|c|}{2018} \\
\hline & Sole & Intercrop & Mean & Sole & Intercrop & Mean \\
\hline$T_{1}-100 \%$ NPK (RDF) & 63.02 & 61.30 & 62.16 & 65.14 & 63.23 & 64.18 \\
\hline $\mathrm{T}_{2^{-}} \mathbf{5 0 \%} \mathrm{N} \& \mathbf{5 0 \%} \mathrm{FYM}$ & 61.90 & 60.66 & 61.28 & 64.02 & 62.59 & 63.30 \\
\hline $\mathrm{T}_{3^{-}} \mathbf{1 0 0 \%} \mathrm{FYM}$ & 59.38 & 58.42 & 58.90 & 61.50 & 60.35 & 60.92 \\
\hline $\mathrm{T}_{4}-\mathbf{5 0 \%} \mathrm{N} \& \mathbf{5 0 \%} \mathrm{VC}$ & 61.62 & 60.41 & 61.01 & 63.74 & 62.34 & 63.04 \\
\hline $\mathrm{T}_{5}-100 \% \mathrm{VC}$ & 58.63 & 57.84 & 58.23 & 60.74 & 59.77 & 60.26 \\
\hline \multirow[t]{2}{*}{ Mean } & 60.91 & 59.72 & & 63.03 & 61.65 & \\
\hline & Intercrop & Fertilizer & I $x \mathbf{F}$ & Intercrop & Fertilizer & $\mathbf{I} \mathbf{x} \mathbf{F}$ \\
\hline SEm \pm & 0.06 & 0.10 & 0.14 & 0.06 & 0.10 & 0.14 \\
\hline CD $(5 \%)$ & 0.19 & 0.30 & 0.42 & 0.19 & 0.30 & 0.42 \\
\hline
\end{tabular}

Table.2 Effect of intercropping and integrated nutrient application on number of fruits per plant of tomato

\begin{tabular}{|c|c|c|c|c|c|c|}
\hline \multirow[t]{2}{*}{ Treatments } & \multicolumn{3}{|c|}{2017} & \multicolumn{3}{|c|}{2018} \\
\hline & Sole & Intercrop & Mean & Sole & Intercrop & Mean \\
\hline$T_{1}-100 \%$ NPK (RDF) & 9.53 & 5.73 & 7.63 & 9.73 & 5.85 & 7.79 \\
\hline $\mathrm{T}_{2-} \mathbf{5 0 \%} \mathrm{N} \& \mathbf{5 0 \%} \mathrm{FYM}$ & 8.60 & 5.18 & 6.89 & 8.78 & 5.39 & 7.08 \\
\hline $\mathrm{T}_{3^{-}} \mathbf{1 0 0 \%} \mathrm{FYM}$ & 7.78 & 4.86 & 6.32 & 7.82 & 4.88 & 6.35 \\
\hline $\mathrm{T}_{4}-\mathbf{5 0 \%} \mathrm{N} \& \mathbf{5 0 \%} \mathrm{VC}$ & 8.54 & 5.11 & 6.83 & 8.63 & 5.33 & 6.98 \\
\hline $\mathrm{T}_{5}-100 \% \mathrm{VC}$ & 6.69 & 4.76 & 5.72 & 6.83 & 4.97 & 5.90 \\
\hline \multirow[t]{2}{*}{ Mean } & 8.23 & 5.13 & & 8.36 & 5.28 & \\
\hline & Intercrop & Fertilizer & $\mathbf{I} \times \mathbf{F}$ & Intercrop & Fertilizer & I $\mathbf{x} \mathbf{F}$ \\
\hline SEm \pm & 0.09 & 0.15 & 0.22 & 0.09 & 0.15 & 0.21 \\
\hline CD $(5 \%)$ & 0.29 & 0.46 & 0.65 & 0.28 & 0.45 & 0.64 \\
\hline
\end{tabular}


Table.3 Effect of intercropping and integrated nutrient application on average fruit weight $(\mathrm{g})$ of tomato

\begin{tabular}{|c|c|c|c|c|c|c|}
\hline \multirow[t]{2}{*}{ Treatments } & \multicolumn{3}{|c|}{2017} & \multicolumn{3}{|c|}{2018} \\
\hline & Sole & Intercrop & Mean & Sole & Intercrop & Mean \\
\hline$T_{1}-100 \%$ NPK (RDF) & 25.67 & 18.59 & 22.13 & 26.80 & 19.41 & 23.11 \\
\hline $\mathrm{T}_{2^{-}} \mathbf{5 0 \%} \mathrm{N} \& \mathbf{5 0 \%} \mathrm{FYM}$ & 22.88 & 16.66 & 19.77 & 23.90 & 17.39 & 20.64 \\
\hline $\mathrm{T}_{3}-100 \%$ FYM & 21.99 & 15.89 & 18.94 & 22.93 & 16.60 & 19.76 \\
\hline $\mathrm{T}_{4}-\mathbf{5 0 \%} \mathrm{N} \& \mathbf{5 0 \%} \mathrm{VC}$ & 22.06 & 16.43 & 19.24 & 23.07 & 17.16 & 20.11 \\
\hline $\mathrm{T}_{5}-100 \% \mathrm{VC}$ & 20.55 & 15.59 & 18.07 & 20.93 & 16.28 & 18.60 \\
\hline \multirow[t]{2}{*}{ Mean } & 22.63 & 16.63 & & 23.53 & 17.37 & \\
\hline & Intercrop & Fertilizer & I $\times \mathbf{F}$ & Intercrop & Fertilizer & $\mathbf{I} \mathbf{x} \mathbf{F}$ \\
\hline SEm \pm & 0.10 & 0.15 & 0.22 & 0.11 & 0.17 & 0.24 \\
\hline CD $(5 \%)$ & 0.30 & 0.47 & 0.67 & 0.32 & 0.51 & 0.73 \\
\hline
\end{tabular}

Table.4 Effect of intercropping and integrated nutrient application on yield (q) per plant of tomato

\begin{tabular}{|c|c|c|c|c|c|c|}
\hline \multirow[t]{2}{*}{ Treatments } & \multicolumn{3}{|c|}{2017} & \multicolumn{3}{|c|}{2018} \\
\hline & Sole & Intercrop & Mean & Sole & Intercrop & Mean \\
\hline$T_{1}-100 \%$ NPK (RDF) & 90.55 & 39.48 & 65.02 & 96.61 & 42.06 & 69.34 \\
\hline $\mathrm{T}_{2^{-}} \mathbf{5 0 \%} \mathrm{N} \& \mathbf{5 0 \%} \mathrm{FYM}$ & 72.88 & 32.00 & 52.44 & 77.67 & 34.77 & 56.22 \\
\hline $\mathrm{T}_{3-} \mathbf{1 0 0 \%}$ FYM & 63.40 & 28.59 & 46.00 & 66.36 & 29.97 & 48.17 \\
\hline $\mathrm{T}_{4}-\mathbf{5 0 \%} \mathrm{N} \& \mathbf{5 0 \%} \mathrm{VC}$ & 69.74 & 31.11 & 50.43 & 73.74 & 33.79 & 53.76 \\
\hline $\mathrm{T}_{5}-100 \% \mathrm{VC}$ & 50.89 & 27.56 & 39.22 & 52.91 & 30.03 & 41.47 \\
\hline Mean & 69.49 & 31.75 & & 73.46 & 34.13 & \\
\hline & Intercrop & Fertilizer & $\mathbf{I} \times \mathbf{F}$ & Intercrop & Fertilizer & $\mathbf{I} \mathbf{x} \mathbf{F}$ \\
\hline SEm \pm & 0.71 & 1.13 & 1.60 & 0.77 & 1.21 & 1.72 \\
\hline CD $(5 \%)$ & 2.13 & 3.36 & 4.76 & 2.28 & 3.61 & 5.11 \\
\hline
\end{tabular}




\section{Average fruit weight (g) per plant}

The average fruit weight per plant of tomato significantly differed in both the years under sole crop in response to fertilizer (Table 3). When tomato was grown in open condition $T_{1}$ showed the maximum average fruit weight $(25.67 \mathrm{~g})$ followed by $\mathrm{T}_{2}(22.88 \mathrm{~g})$ and $\mathrm{T}_{4}$ (22.06 g) in kharif 2017. In kharif 2018 again $\mathrm{T}_{1}(26.80 \mathrm{~g})$ recorded the maximum average fruit weight, followed by $\mathrm{T}_{2}(23.90 \mathrm{~g})$ and $\mathrm{T}_{4}$ $(23.07 \mathrm{~g})$. The lowest average fruit weight was recorded in $\mathrm{T}_{5}(20.55 \mathrm{~g}$ and $20.93 \mathrm{~g})$ for the year 2017 and 2018 respectively. The average fruit weight varied significantly under the shade and maximum average fruit weight was recorded in $\mathrm{T}_{1}(18.59 \mathrm{~g})$ followed by $\mathrm{T}_{2}$ $(16.66 \mathrm{~g})$ and $\mathrm{T}_{4}(16.43 \mathrm{~g})$ in 2017 . In year 2018, maximum average fruit weight was also recorded in treatment combination $\mathrm{T}_{1}$ (19.41 g) followed by $T_{2}(17.39 \mathrm{~g})$ and $T_{4}(17.16 \mathrm{~g})$. $\mathrm{T}_{5}$ showed the minimum average fruit weight of $15.59 \mathrm{~g}$ and $16.28 \mathrm{~g}$ in 2017 and 2018 respectively under the tree canopy. The average fruit weight was significantly reduced when compared across the systems i.e. sole and under shade in both the years. Significant difference was recorded in interaction effect of intercrop and fertilizer application in year $2017 \& 2018$. The reduction in fruit weight may be due to lower photosynthetic rate. Similar results were also reported by Miah (2000).

\section{Yield (q) per hectare}

A perusal of the data in table 4 indicated that per hectare yield of tomato in all the five treatments differed significantly in both the years under sole crop and intercrop. When tomato was grown in open condition, $\mathrm{T}_{1}$ showed the maximum yield $(90.55 \mathrm{q})$ followed by $\mathrm{T}_{2}(72.88 \mathrm{q})$ and $\mathrm{T}_{4}(69.74 \mathrm{q})$ in kharif 2017. Also in kharif $2018 \mathrm{~T}_{1}(96.61 \mathrm{q})$ recorded the maximum yield, followed by $\mathrm{T}_{2}$ (77.67 q) and $\mathrm{T}_{4}(73.74 \mathrm{q})$. The lowest yield was recorded in $\mathrm{T}_{5}(50.89 \mathrm{q}$ and $52.91 \mathrm{q})$ for the year 2017 and 2018 respectively under sole crop. Under the shade the maximum yield was attained in treatment $\mathrm{T}_{1}(39.48 \mathrm{q})$ followed by $\mathrm{T}_{2}(32.00 \mathrm{q})$ and $\mathrm{T}_{4}(31.11 \mathrm{q})$ in 2017. In year 2018, maximum yield was also recorded in treatment combination $\mathrm{T}_{1}$ (42.06 q) followed by $\mathrm{T}_{2}(34.77 \mathrm{q})$ and $\mathrm{T}_{4}(33.79 \mathrm{q})$. $\mathrm{T}_{5}$ showed the minimum yield of $27.56 \mathrm{q}$ and $30.03 \mathrm{q}$ in 2017 and 2018 respectively. Per hectare yield significantly reduced when tomato was grown under the tree canopy. The interaction effect of intercrop and fertilizer application was significant in year 2017 \& 2018. Adeleye et al., (2010); Adeoye and Agboola (1985) and Ogunwale (2003) reported that the more readily nutrients are available to a crop, the higher the performance of the crop and vice versa. Similar reduction in yield of intercrops under trees than sole cropping was observed by Makinde et al., (2016), Ravi et al., (2009) under Ailanthus excelsa based agro forestry system and by Rishi et al., (2011) under Populus deltoids and Melia composita based agro forestry systems.

\section{References}

Adeleye, E. O., Ayeni, L. S. and Ojeniyi, S. O. 2010. Effect of poultry manure on soil physico-chemical properties, leaf nutrient contents and yield of yam (Dioscorea rotundata) on Afisol soil in South Western Nigeria. J. American Sci., 6(10): 871-878.

Adeoye, G. O. and Agboola, A. A. 1985. Critical levels for soil $\mathrm{pH}$, available $\mathrm{P}$, $\mathrm{K}, \mathrm{Zn}, \mathrm{Mn}$, and maize ear leaf content of $\mathrm{P}, \mathrm{Cu} \mathrm{Mn}$ on sedimentary soils of South-Western Nigeria. Fertilizer Res., 6(1): 65-67.

Bose, T. K. and Som, M. G. 1986. Vegetable crops in India, Mitra, B. Naya Prokash, Bidhansanani, Calcutta. 700006, India. 293-342 
Divya, M. P., Neelakantan, K. S., Ayyasamy, M., Yogajayand, J., Kalaiselvi, T. and Jerlin, R. 2005. Studies on the compatibility of agricultural crops with important agro forestry tree species. Paper presented on workshop on agro forestry for Attapady wastelands potential and prospects. Jan, 8-9, 2005, Palakkad, Kerala.

Makinde, A. I., Jokanola, O. O., Adedeji, J. A., Awogbade, A. L. and Adekunle, A. F. 2016. Impact of organic and inorganic fertilizers on the yield, lycopene and some minerals in tomato (Lycopersicum esculentum) fruit. European J. Agric. \& Forestry Res., 4(1): 18-26.

Miah, M.M. 2000. Performance of five winter vegetables under different light conditions for agroforestry systems. M.S. Thesis, Department of Agroforestry, Bangabandhu Skeikh Mujibar Rahman Agricultural University, Salna, Gazipur.

Mohan Raj, T. (2004). Studies on compatibility of agricultural crops with Simarouba glauca DC. M.Sc. Thesis, TNAU, Coimbatore, India.

Nnabude, P. C., Nweke, I. A. and Nsoanya, L. N. 2015. Response of three varieties of tomatoes (Lycopersicon esculentum) to liquid organic fertilizer (NPK 20:10:10) and for soil improvements. European J. Physical \& Agric. Sci., 3(2): 28-35.

Ogunwale, J. A. 2003. Soil phosphorus and phosphate fixation. Third in the series, Faculty of Agriculture, University of Ilorin, Nigeria pp. 20.

Rajalingam, G. V., Divya, M. P., Prabaharan C. and Parthiban, K. T. 2016. Performance of vegetable crops under Ailanthus excelsa based agroforestry system Indian J. of Agroforestry Vol. 18(1): 16-20.

Ravi, R., Divya, M. P. and Rathakrishnan, P. 2009. Evaluation of fodder crops under Ailanthus excelsa Roxb. based agroforestry system. Indian. $J$. Agroforestry, 11(2): 90-93.

Rishi, Gill, I. S., Kaur, N. and Singh, B. 2011. Performance of trees and crops under organic manure treatments in Populus deltoids and Melia composita based agro forestry system. Indian $j$. agroforestry, 13(1): 44-50.

Tisdale, S. L., Nelson, W. L., Beaton, J. D. and Havlin, J. L. 2003. Soil fertility and fertilizers. 5th Edn., Prentice-Hall of India, Pvt. Ltd., New Delhi.

\section{How to cite this article:}

Lalit Upadhyay, S. K. Gupta, Sandeep Sehgal and Arvinder Kumar. 2020. A Study on Performance of Lycopersicon esculentum under Poplar Based Agroforestry System in Subtropics of Jammu (J\&K). Int.J.Curr.Microbiol.App.Sci. 9(09): 2893-2899.

doi: https://doi.org/10.20546/ijcmas.2020.909.356 